\title{
Urbanization development on river hydrology
}

\author{
Sardorbek Musayev ${ }^{1, *}$, Ilhomjon Musaev $^{2}$, Mashkhurakhon Nuretdinova ${ }^{3}$, and Doniyor \\ Eshnazarov ${ }^{3}$ \\ ${ }^{1}$ University of Connecticut, Department of Civil and Environmental Engineering, Storrs, CT, USA \\ ${ }^{2}$ Tashkent Institute of Irrigation and Agricultural Mechanization Engineers, Department of Geodesy \\ and Geoinformatics, Kari Niyazi str., 39, 100000, Tashkent, Uzbekistan \\ ${ }^{3}$ State Research Project Institute "Uzdavyerloyiha", Choponota str., Chilanzar-C massif, Tashkent, \\ 100097, Uzbekistan
}

\begin{abstract}
In this study both data of land use and land cover were compared for selected period of time it is obvious that urban area is significantly increased in Saline River watershed, Arkansas, USA. For hydrologic studies and analysis WMS 8.1 program was used to delineate the watershed and analysis of other hydrologic processes. For further analysis, HEC-HMS was used to analyze the results of hydrographs of peak flows. Results show there is impact to hydrologic processes due to urbanization.
\end{abstract}

\section{Introduction}

Population of the Earth is significantly increasing with a shift of $60 \%$ would live in urban areas by $2030[1,2]$. This puts the pressure to ecological footprint of consumption of environmental and natural resources. Urbanization along with land use and land changes has an impact to natural ecosystems [2-4].

A watershed modeling due to increase in urbanization has significant environmental concern. It is a three-dimensional and explanatory representation of land that drains to a single river, stream, lake, or ocean [5]. A watershed model is used as a tool to educate people about the changes of their watershed, consequences of urbanization and their security associated with flood generated by rising of peak flows $[5,6,16]$.

The study area is the Trace Creek - Saline River watershed of the Hydrologic Cataloguing Systems (HUC) unit 080402030703, one of the subwatershed of Upper Saline Watershed system located in Saline County, Arkansas [7, 11]. The watershed is the $54.52 \mathrm{mi}^{2}$ drainage area. Due to increasing business expansion, population of the area increased from 4,774 to 5,817 during 1990 to 2000 respectively. This favors the intensification in urbanization [8]. Density also increased from 87.56 persons $/ \mathrm{mi}^{2}$ to 106.69 persons $/ \mathrm{mi}^{2}$ in between $1990-2000$. Fig. 1 shows population change in ten years and increase for $21.84 \%[9,11,17]$.

The Trace Creek - Saline River watershed was taken as a study area and lies within the Arkansas River Basin, Central Arkansas (Fig. 2). The study divides the watershed into 2

\footnotetext{
* Corresponding author: sardorbek.musayev@uconn.edu
} 
subbasins to focus more on each subbasin. Our analysis of the watershed uses the curve number method to calculate surface runoff volumes and peak flows.

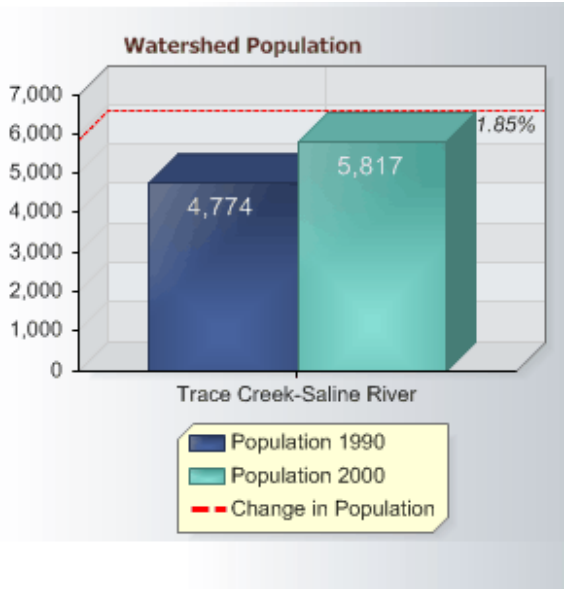

Fig. 1. Increasing population in the watershed.

Soil Conservation Service developed this method to characterize the runoff from merging land use and soil data as a curve number for runoff [12]. The curve numbers for each subbasin were calculated from digital soil and land use data using WMS 8.1 [11, 12].

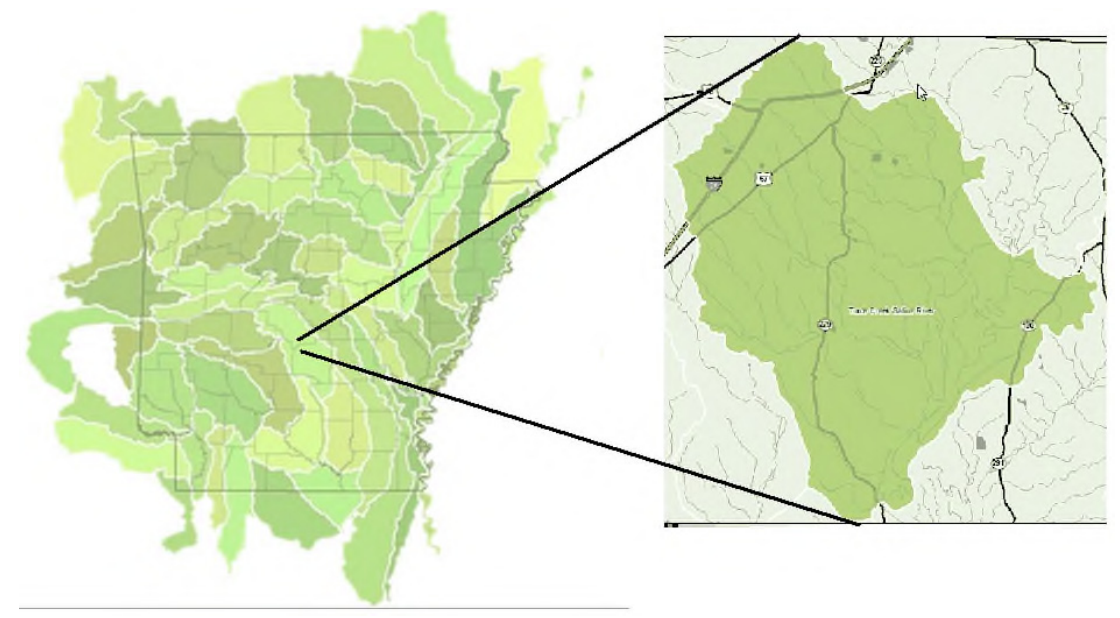

Fig. 2. Location of the study area.

Land use maps for 1999 and 2006 are shown in Fig. 3 below. Comparing both data from 1999 and 2006 given above it is obvious that urban area is increased from $1.98 \mathrm{mi}^{2}$ to 8.17 $\mathrm{mi}^{2}$ which indicates increase for $11.48 \%$. On the other hand, deforestation reduced the forested area for $9.48 \%$ with area diminishing for $5.21 \mathrm{mi}^{2}$ [13]. The difference in agricultural pasture presents $2.22 \%$. Minor changes in bare soil also were observed. 


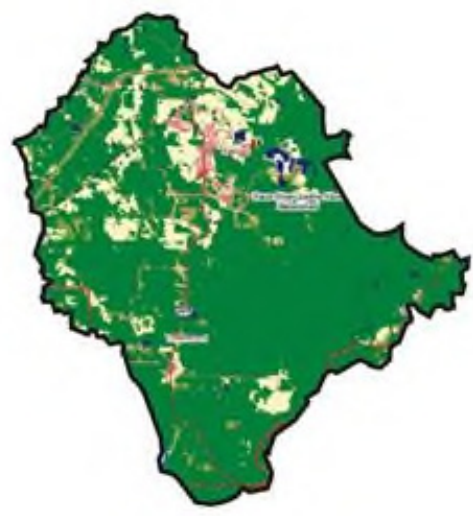

Land Use / Land Cover for 1999

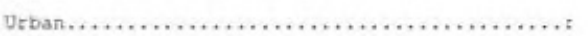

Bare ................................

water $\ldots+++\ldots \ldots \ldots++\ldots \ldots \ldots+\ldots \ldots \ldots \ldots \ldots \ldots$.

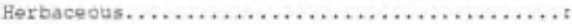

Forestr.

Agrt - Crops.....t+t......................

Agrt - pasturo......................

\begin{tabular}{r}
305 70.01 \\
\hline 3.678 \\
.028 \\
1.068 \\
4.914 \\
77.798 \\
-.08 \\
12.558
\end{tabular}

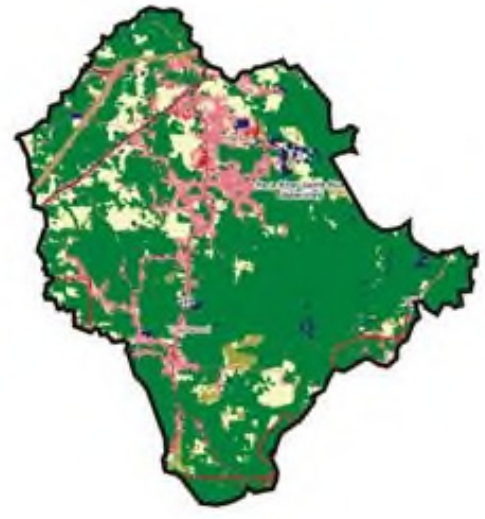

Land Use / Land Cover for 2006

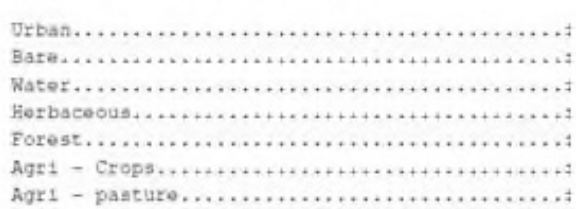

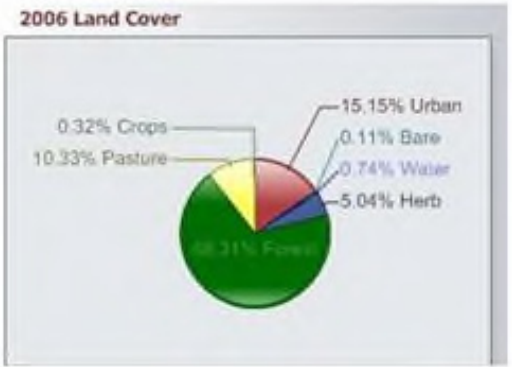

Fig. 3. Landuse and land cover data for 1999 and 2006.

\begin{tabular}{rr} 
Sq. Miles & Vot Total \\
\cline { 2 - 2 } 8.17 & 15.151 \\
.06 & .114 \\
.40 & .745 \\
2.72 & 5.045 \\
36.84 & 68.314 \\
.17 & .324 \\
5.57 & 10.334
\end{tabular}




\section{Materials and methods}

Precipitation data generated for 100 year 24 hour for selected watershed area using HydrolInf 5.0 (Fig. 4). Rainfall depth for the area is 8.25 inches [14, 15].

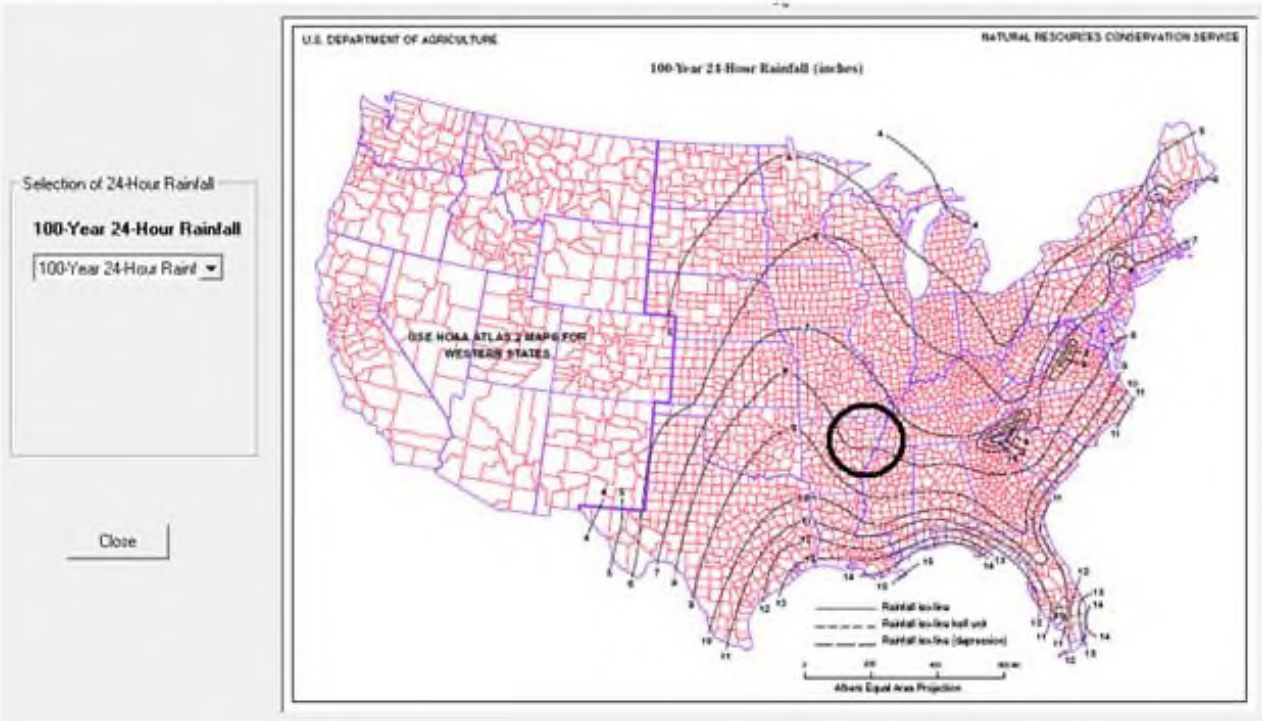

Fig. 4. Precipitation data.

Watershed digital elevation data (DEM) was retrieved from USGS. WebGIS and EPA provided digital land use, soil type data for conducting study [9, 12]. The data are then entered into WMS 8.1 (Fig. 5). Watershed is delineated and other required parameters such as $\mathrm{CN}$ are calculated using SCS CN method. File is converted into HEC-HMS as ready product for further analyses. The results of hydrographs presenting peak flows for each 1999 and 2006 are contrasted in HEC-HMS program.

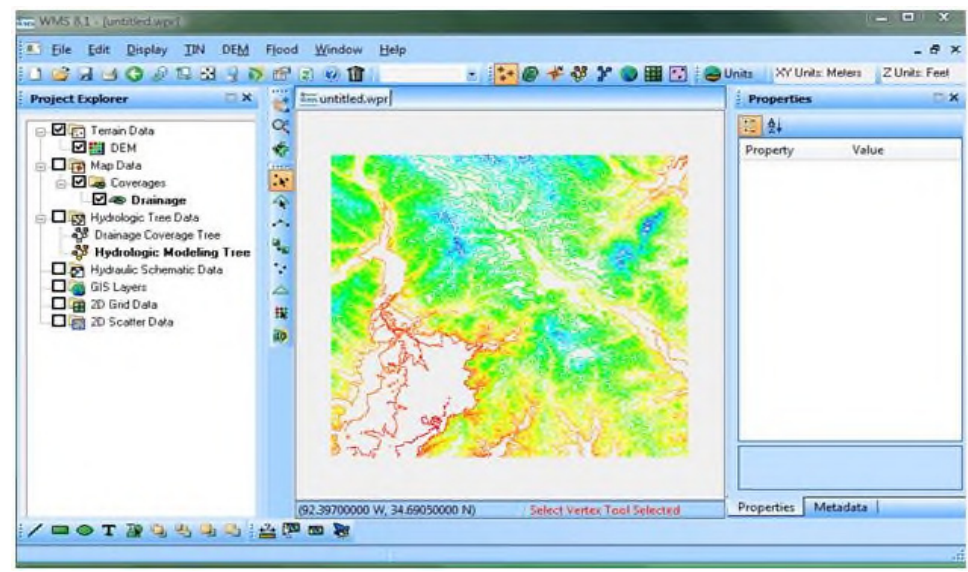

Fig. 5. DEM data for selected watershed area in WMS interface.

Curve number plays an important role in peak flow study. WMS is able to calculate CN based on land use data and soil type data for designated area $[8,10]$. We entered soil type data first and then land use data in the program. System error might occur due to 
uncorrelated coordinate systems. Thus, coordinate conversion section of the program should be thoroughly checked. Geographic data (latitude and longitude locations) is not compatible with UTM data. Therefore, user may experience these data not overlapping each other. Watershed Land Use and soil type area are selected with adjacent vicinity for calculate $\mathrm{CN}$ at later stage (Fig. 6).

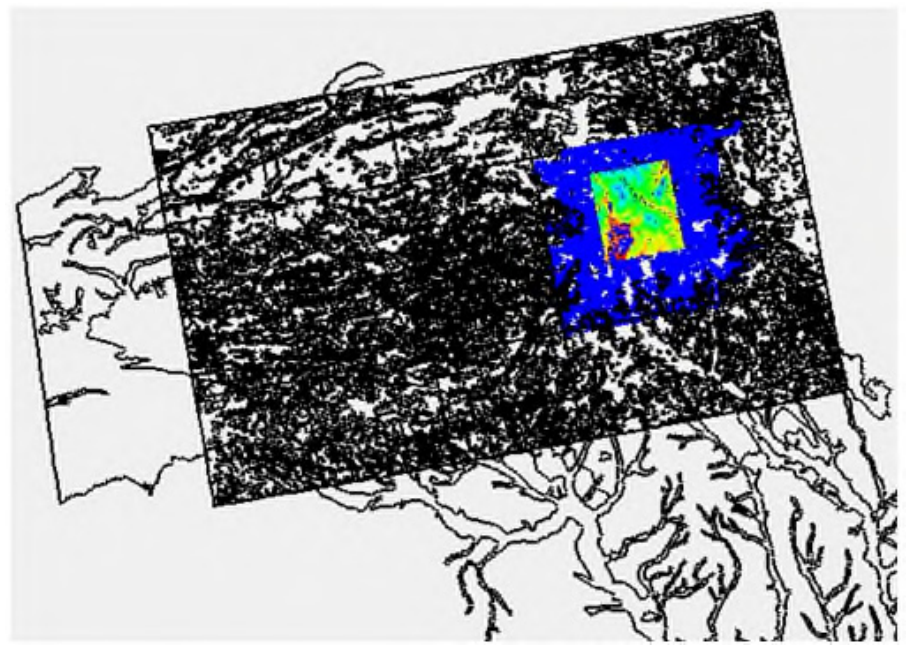

Fig. 6. Land Use area selection.

Once land use and soil data are processed watershed delineation procedure can be commenced (Fig. 7). Computation of flow channels enables to select watershed outlet. TOPAZ computation for determining channel flow. This watershed area is $50.34 \mathrm{mi}^{2}$ shows smaller area than actual watershed area. Actually watershed area can be extended through some underland engineering pipelines to divert water into the channel and this specific can be supplemented into watershed manually. WMS performs the procedure based on DEM data and relief of the area.

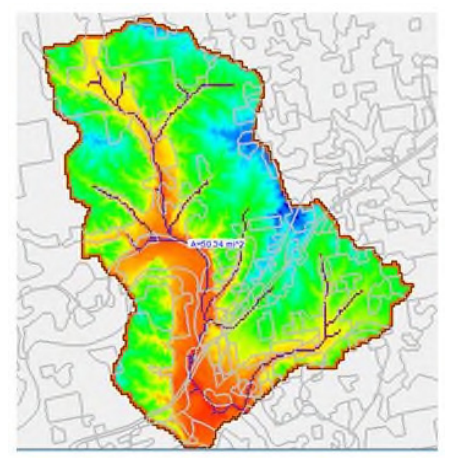

Fig. 7. Watershed delineation.

Computation of $\mathrm{CN}$ requires to know soil type and group of watershed. Fig. 8 displays area, perimeter and specific ID number and soil group. Based on soil moisture condition soil group can be A, B, C or D. A and B allow more water to infiltrate so runoff generation is expected less comparing to $\mathrm{C}$ and $\mathrm{D}$ generates more surface runoff with a smaller amount of infiltration. Therefore, for watershed analysis knowing soil condition is important. 


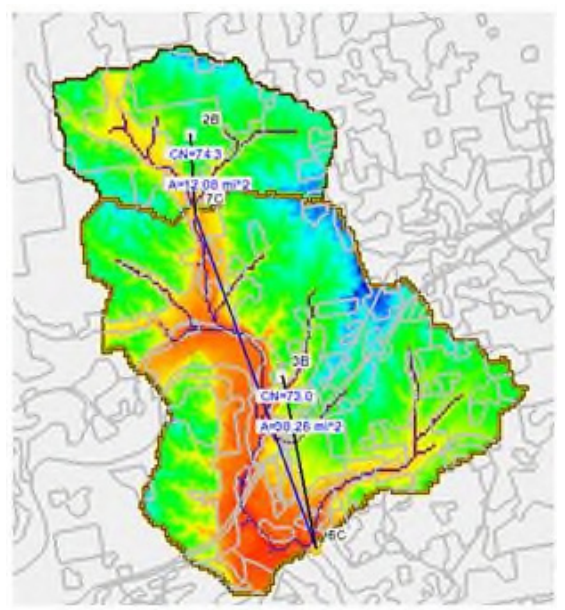

Fig. 8. Subbasins and calculation of CN.

For routing calculation Muskingum method is selected and introduced. For further analyses of peak flow watershed area data processed in WMS can be transformed into HEC - HMS working environment (Fig. 9).

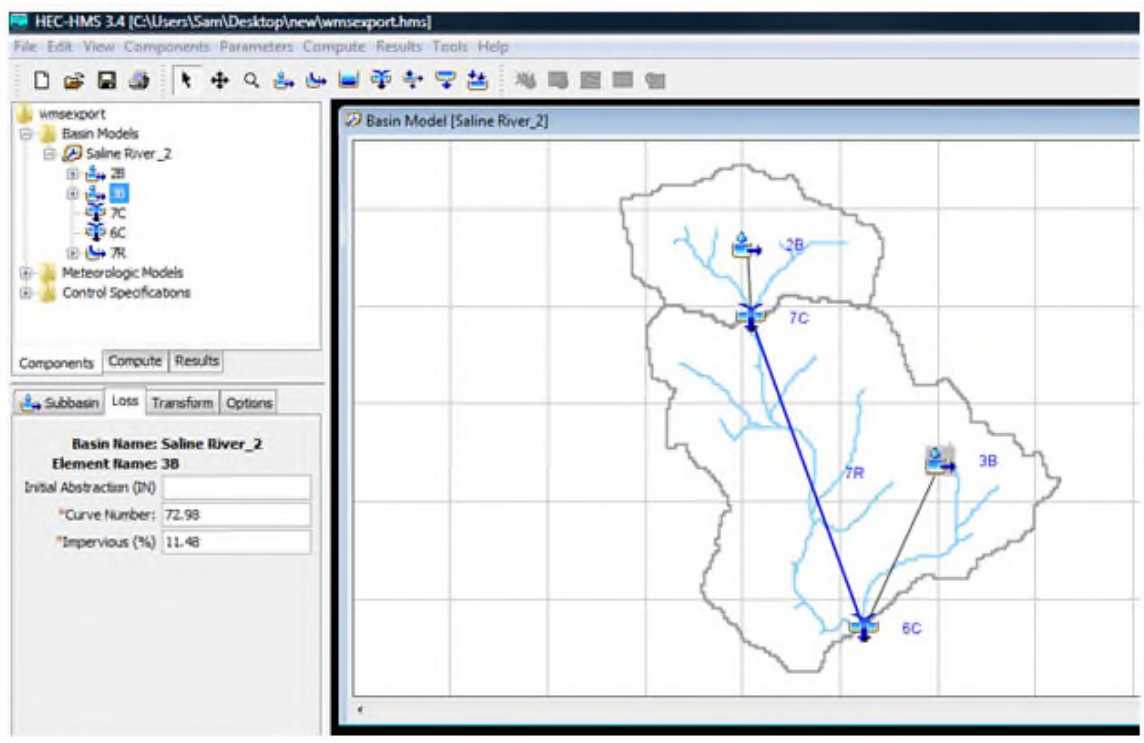

Fig. 9. Watershed in HEC-HMS working environment.

It is convenient that these two program files are compatible to work. In above Fig. 9 watershed with two subbasins $2 \mathrm{~B}$ and $3 \mathrm{~B}$ are shown. $7 \mathrm{C}$ is the outlet for upperstream subbasin and $6 \mathrm{C}$ is the main outlet where all watershed water get concentrated. $7 \mathrm{C}$ and $6 \mathrm{C}$ outlets are connected with $7 \mathrm{R}$ reach channel. $3 \mathrm{~B}$ is also contributing inflow into the main outlet $6 \mathrm{C}$. For hydrologic study and contrasting the peak flow data analyses hydrographs from main outlet $6 \mathrm{C}$ is thoroughly studied. Urbanization decreases soil infiltration capacity with covering the area with impervious layer allowing most rainfall water to runoff. Hydrograph peak flow discharge at outlet increases with the same amount of rainfall after urbanization. 


\section{Results and conclusion}

HEC-HMS gave the range of results for different period of time with same amount of rainfall. Fig. 10 discusses the peak flow scenario in 1999. Based on that 2013 scenario peak flow assumed in Fig. 12 to see the impact of urbanization.

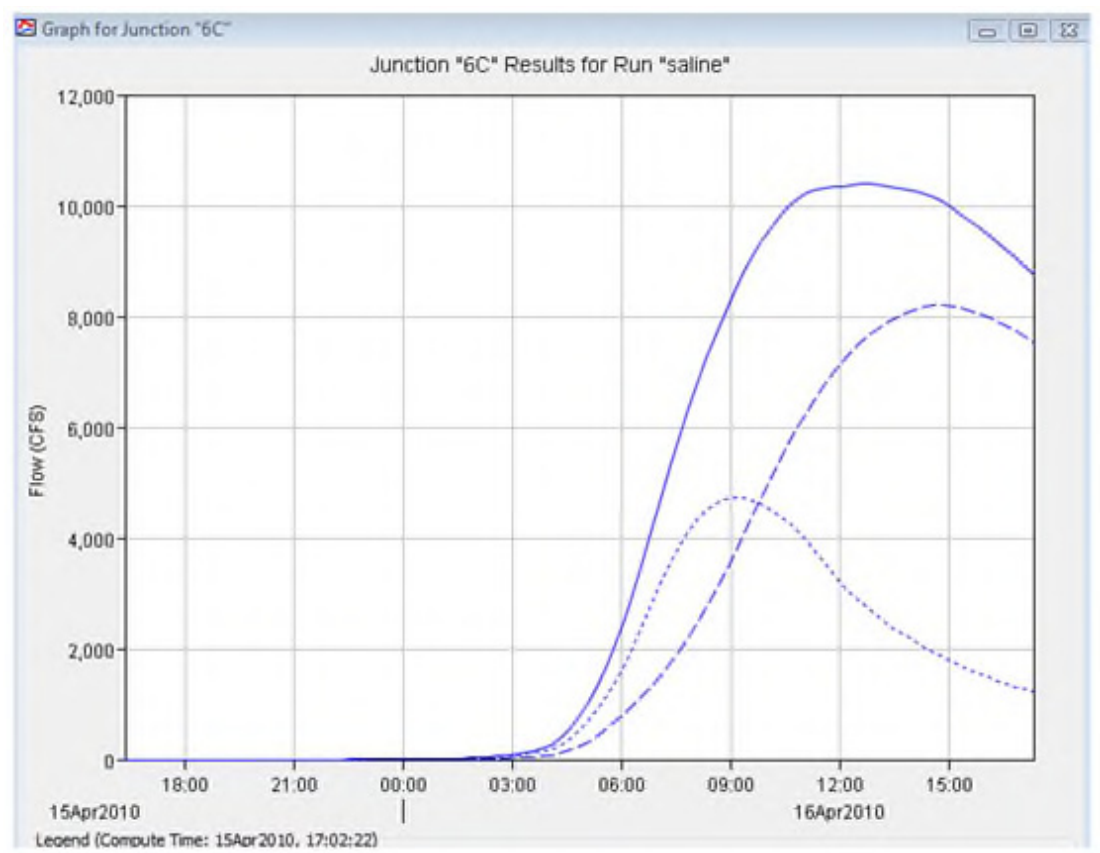

Fig. 10. Flow hydrograph for 1999.

In above 1999 flow hydrograph indicates that peak flow at main outlet is 10,391.6 $\mathrm{ft}^{3} / \mathrm{sec}$. Time to peak flow is at 12:50. Urban area consists of $1.9 \mathrm{mi}^{2}$. Forested and agricultural pasture areas are not affected yet (Fig. 11).

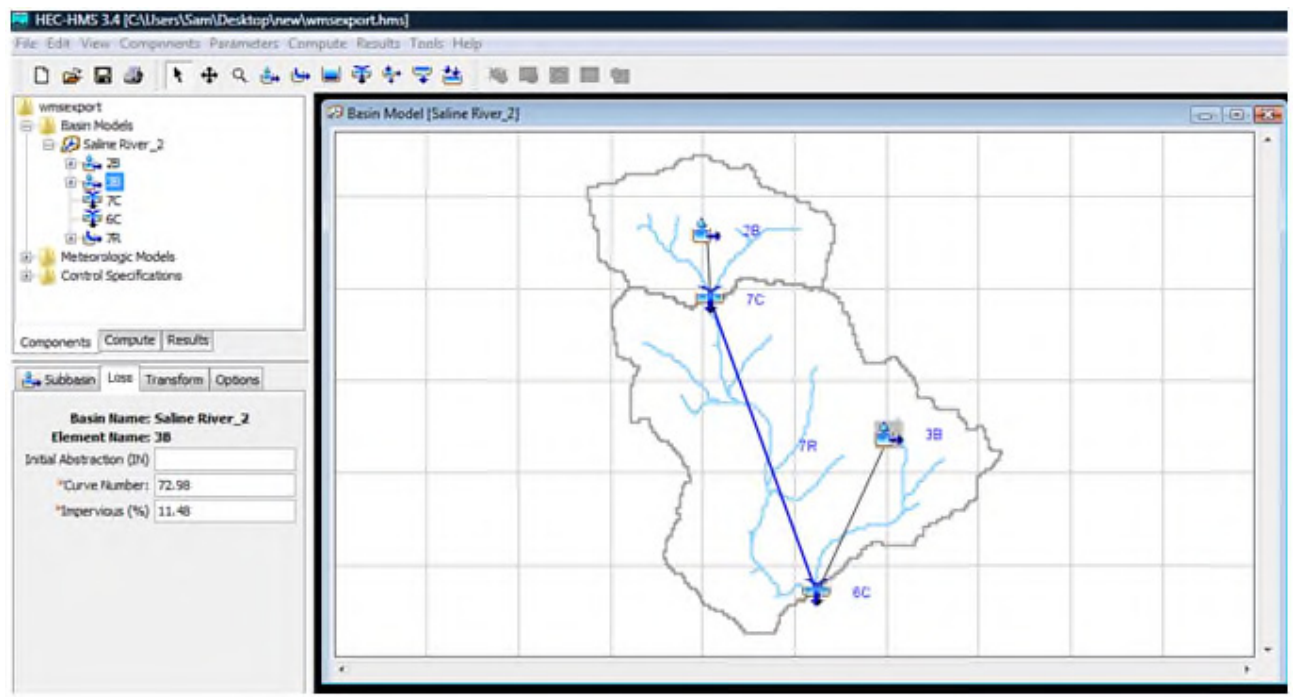

Fig. 11. Increase impervious area. 
In 2006 urban area increased from $1.98 \mathrm{mi}^{2}$ to $8.17 \mathrm{mi}^{2}$ which indicates increase for $11.48 \%$. Therefore, to observe the change impervious area is increased for $11.48 \%$. Deforestation indicates from $41.96 \mathrm{mi}^{2}$ to $36.84 \mathrm{mi}^{2}$ for 1999 and 2006 respectively. Resulted peak flow is $10,960 \mathrm{ft}^{3} / \mathrm{sec}$ shows the increase for $568.4 \mathrm{ft}^{3} / \mathrm{sec}$ in seven years. We did not see the change in peak flow. It stays the same at 12:50 as in 1999.

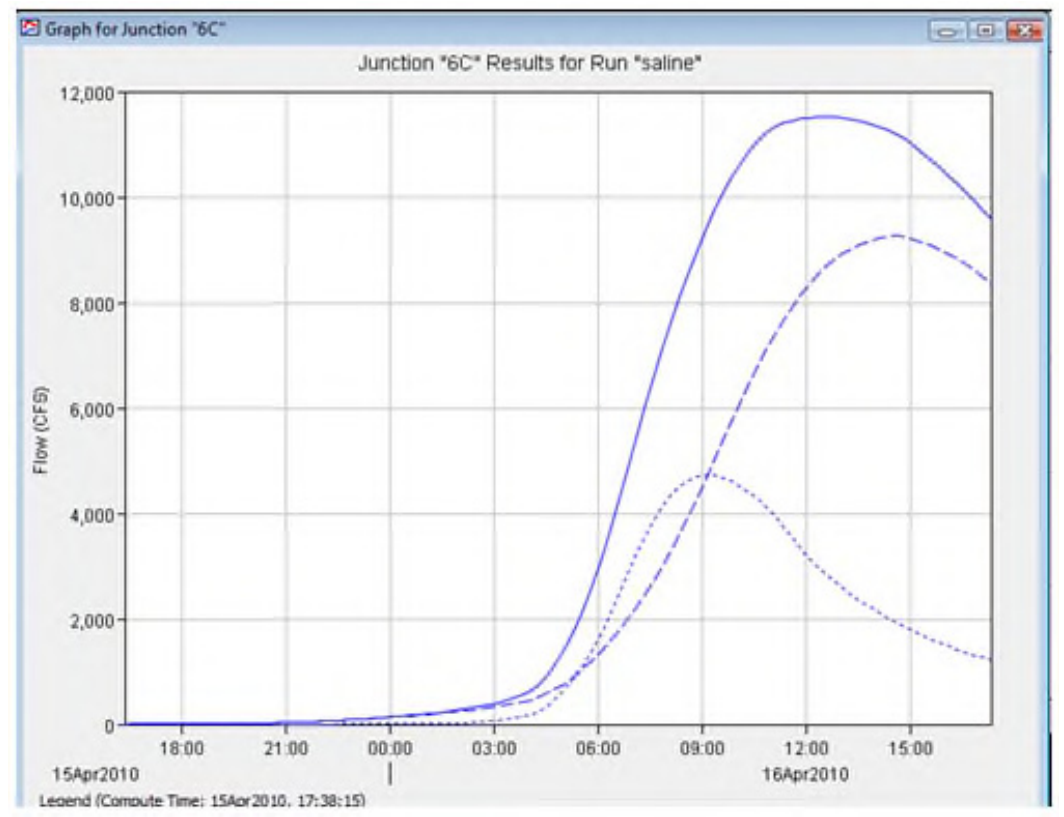

Fig. 12. Flow hydrograph for 2013.

Based on the trend of changes in study area assumption for 2013 can be made (Fig. 12). Impervious area is increased for $22.96 \%$ comparing to 1999 and peak flow expectation is $11,528.5 \mathrm{ft}^{3} / \mathrm{sec}$ for 2013. This is the increase for $1,136.4 \mathrm{ft}^{3} / \mathrm{sec}$ and $568 \mathrm{ft}^{3} / \mathrm{sec}$ to 1999 and 2006 respectively. Peak flow time is decreased from 12:50 to 12:35 for 15 minutes earlier. Peak flow time has also relatively impact on watershed management (Table 1 and Fig.s 13-14).

Table 1. Trend of urbanization change.

\begin{tabular}{|c|c|c|c|}
\hline Year & $\begin{array}{c}\text { Peak flow } \\
\text { (CFS) }\end{array}$ & $\begin{array}{c}\text { Peak flow } \\
\text { time }\end{array}$ & $\begin{array}{c}\text { Change (CFS) for } \\
\mathbf{1 9 9 9}\end{array}$ \\
\hline 1999 & $10,391.6$ & $12: 50$ & - \\
\hline 2006 & 10,960 & $12: 50$ & 568.4 \\
\hline 2013 & $11,528.5$ & $12: 35$ & $1,136.4$ \\
\hline
\end{tabular}




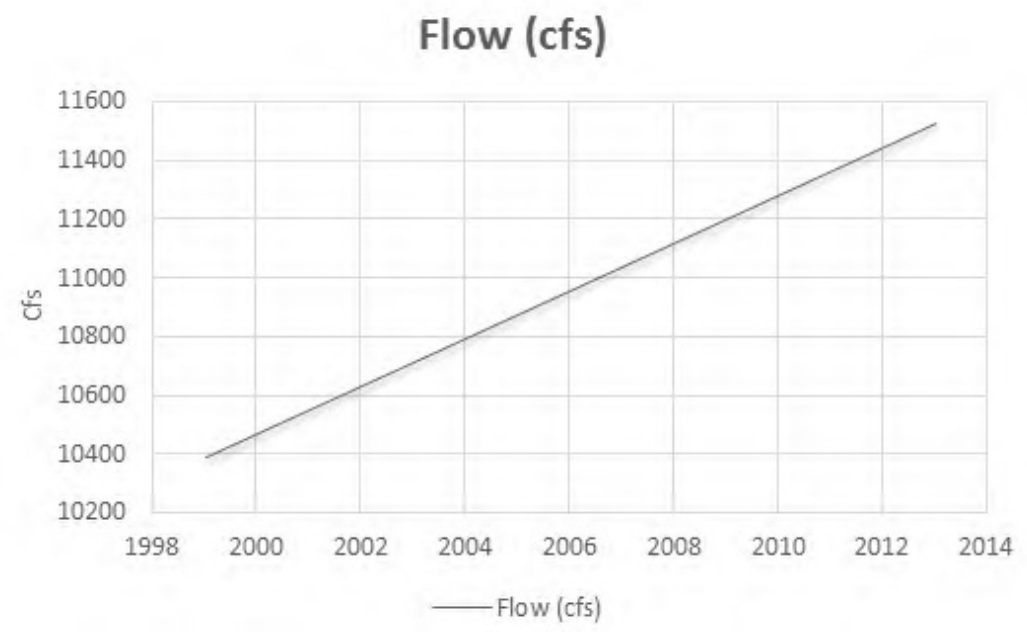

Fig. 13. Observation of urbanization increase.

In above Fig.s the observation of change due to urbanization is clearly represented. As a conclusion we can say that these trends of change allow respective decision makers to decide what measures to take so that impact to watershed such as flood occurrence from high peak flow can be controlled. River management such as restoration or improvement activities will be considered. The effect of more runoff from urban area not only cause flood problems but also associated water quality issues that end up in water bodies such as lakes or rivers which will reciprocally disturbs watershed biotic and abiotic ecosystem.

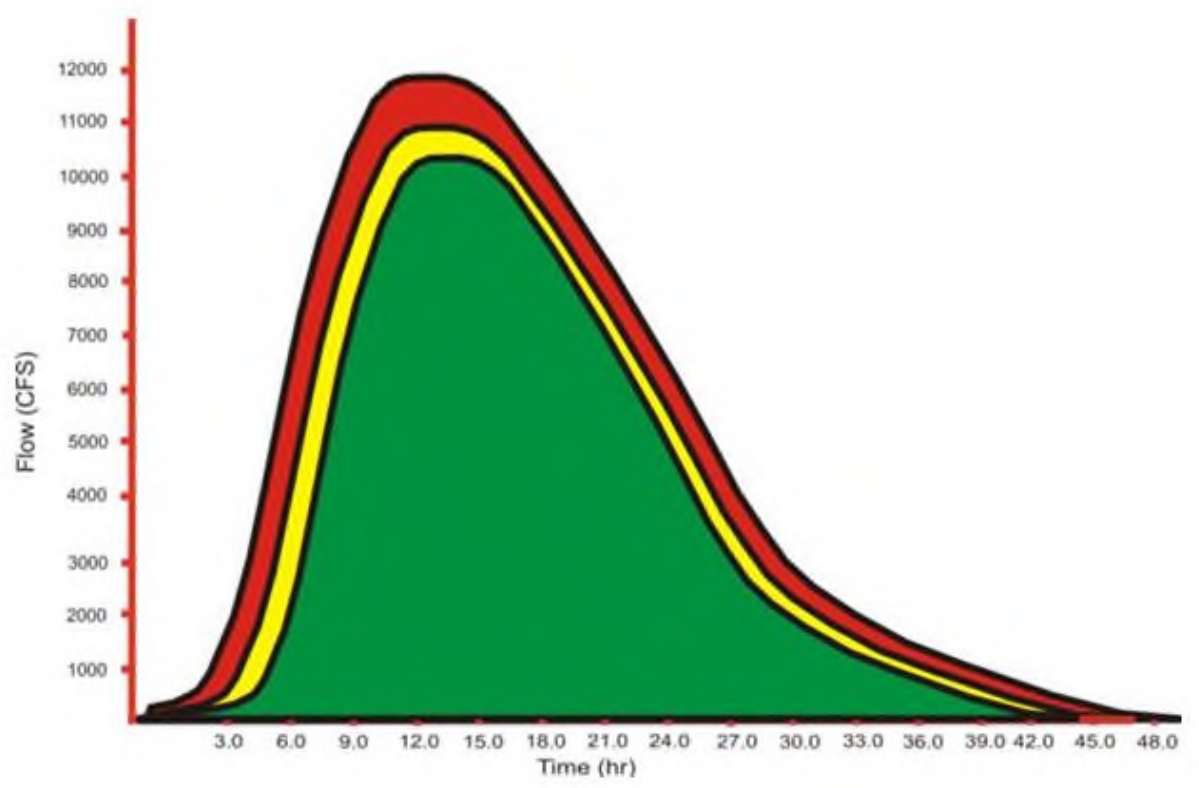

Fig. 14. Hydrographs with peak flows for three consecutive periods: green color - 1999, yellow color - 2006 and red color-2013. 


\section{References}

1. D. B. Booth, B. P. Bledsoe, The Water Environment of Cities, 344 (2009)

2. D. B. Booth, JNABS, 24, 724-737 (2005)

3. T. Hammer, WRR, 8, 1530-1546 (1972)

4. D. B. Booth, P. C. Henshaw, Water Sciences and Applications, 2, 17-38 (2001)

5. J. R. Karr, Eco. Appl., 1, 66-84 (1991)

6. L. Leopold, Geological Society of America Bulletin, 84, 1845-1860 (1973)

7. G. Hollis, WRR, 11(3), 431-435 (1975)

8. S. Burges, M. Wigmosta, J. Meena, JHE, 3, 86-97 (1998)

9. S. P. Faulkner, Wetlands, 216 (2004)

10. P. Groffman, D. Bain, L. Band, K. Belt, G. Brush, Frontiers in Ecology and the Environment, 1, 315-321 (2003)

11. P. Henshaw, D. Booth, JAWRA, 36(6), 1219-1236 (2000)

12. A. Huryn, V. Huryn, C. Arbuckle, L. Tsomides, Fresh. Biol., 47, 401- 415 (2002)

13. C. Konrad, D. Booth, American Fisheries Society Symposium, 47, 157-177 (2005)

14. C. Konrad, D. Booth, S. Burges, WRR, 41, WO7009 (2005)

15. S. Pickett, M. Cadenasso, Annu. Rev. Ecol. Syst., 32,127-157 (2001)

16. K. Khakimova, I. Musaev, A. Khamraliev, E3S Web Conf., 227, 02003 (2021)

17. I. Musaev, A. Bokiev, M. Botirova, E3S Web Conf., 227, 05004 